Elaine Athayde Alves Tedesco ${ }^{1}$

Revista de Artes Visuais

v. 24 n. 42

nov/dez 2019

e-ISSN:2179-8001
ENSAIO VISUAL

\section{O álbum de viagem ${ }^{2}$}

\author{
The travel álbum
}

\section{Resumo}

Este ensaio fotográfico carregado de afeto, é sobre o tempo, esquecimento e impregnações. Nele aproximo imagens de um álbum de fotografias analógicas em preto e branco, do final dos anos 1950 e, uma sequência de fotografias que fiz Berlim, em 2015. O álbum era de minha mãe. As fotos foram tiradas durante a sua viagem de final de curso, uma turnê marítima, que a turma de estudantes de arquitetura da UFRGS fez à Europa, no ano de 1957 (ou seria 1956?). Aquelas fotografias já muito me intrigaram, eram apenas cinco mulheres numa turma de trinta alunos. Quem eram elas e eles? Quem é o autor das fotografias? Não sei.

As relações que estabeleci entre as imagens, procurando convergências que geram impregnações entre lugares, tempos e cenas, narram uma história marcada por lembranças e apagamentos.

\section{Palavras-chave}

Esquecimento. Fotografia. Impregnações. Viagem. Tempo.

\section{Abstract}

This affectionate photographic essay is about time, forgetfulness and impregnations. It brings together images from an analogue black-and-white photo album from the late 1950s, and a sequence of photos I made in Berlin in 2015. The album was from my mother. The photos were taken during their final year voyage, a sea tour, that the UFRGS architecture student class made to Europe in 1957 (or was it 1956?). Those photographs have intrigued me so much, they were just five women in a class of thirty students. Who were they and they? Who is the author of the photographs? Do not know.

The relations I established between the images, looking for convergences that generate impregnations between places, times and scenes, tell a story marked by memories and erasures.

Keywords

Forgetfulness. Photography. Impregnations. Trip. Time.

1- Universidade Federal do

Rio Grande do Sul, Brasi ORCID: 0000-0003-1530-9943

2- Ensaio visual enviado em $06 /$ maio/2019

Ensaio visual publicado em 23/dez/2019 

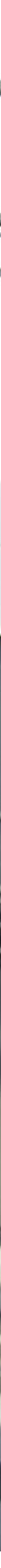


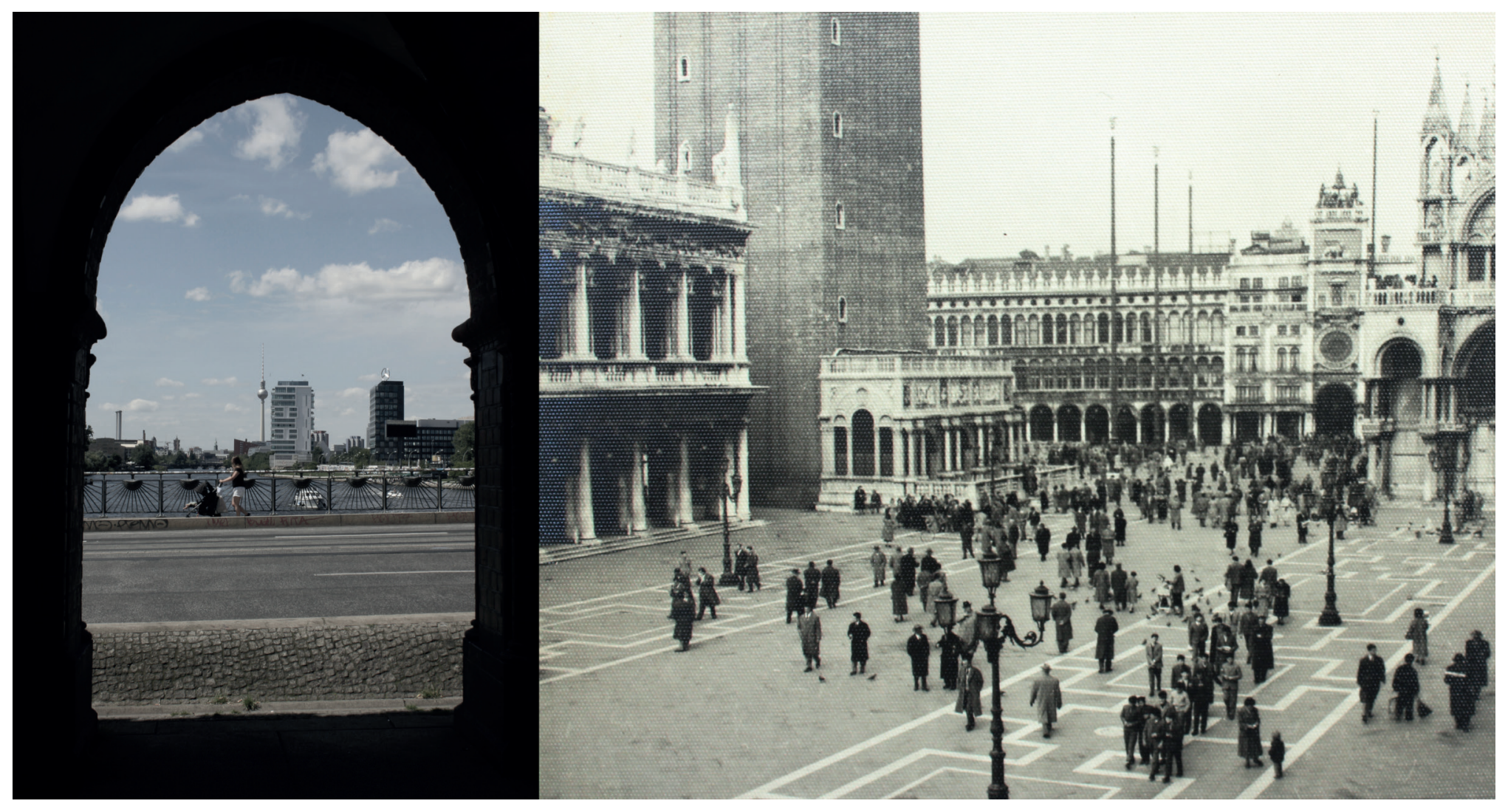




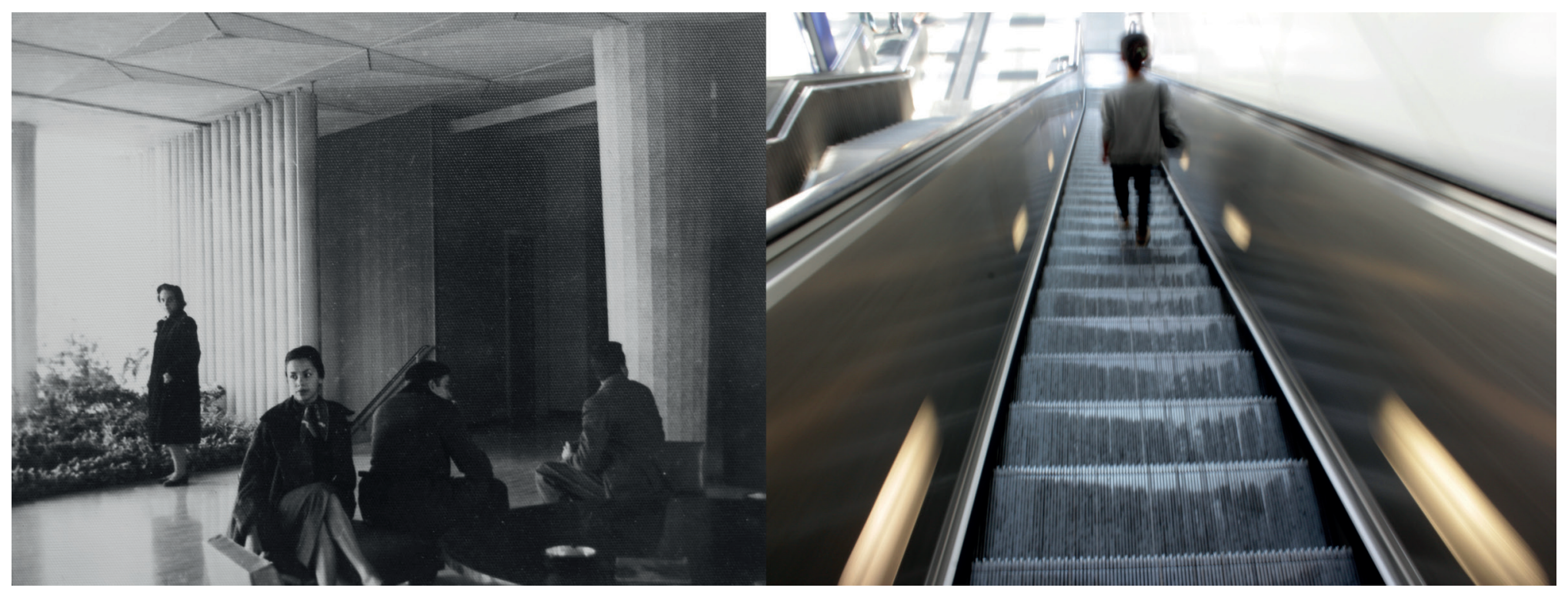




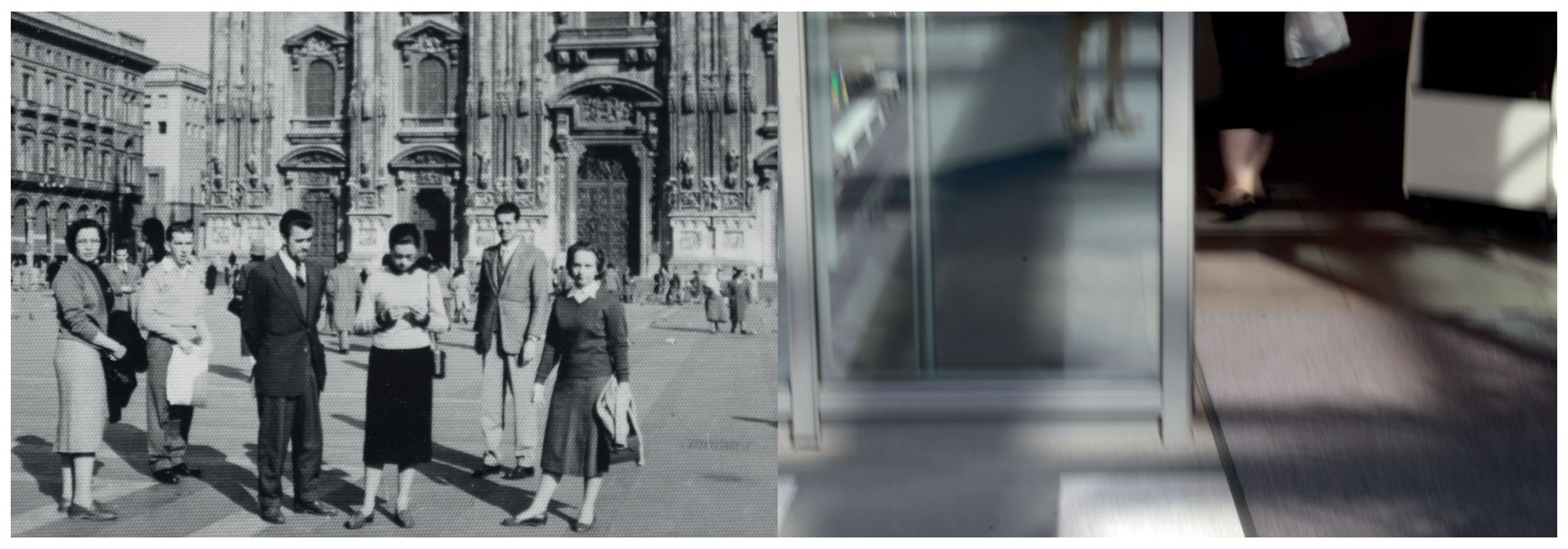




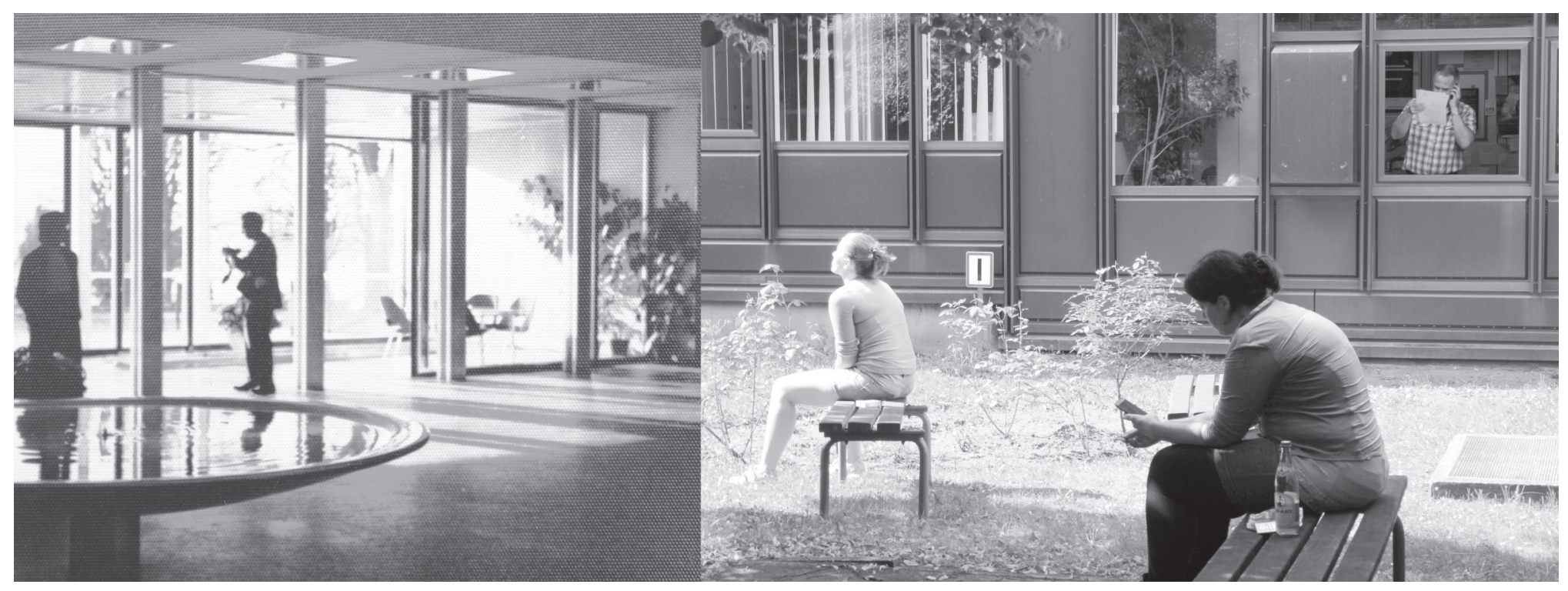




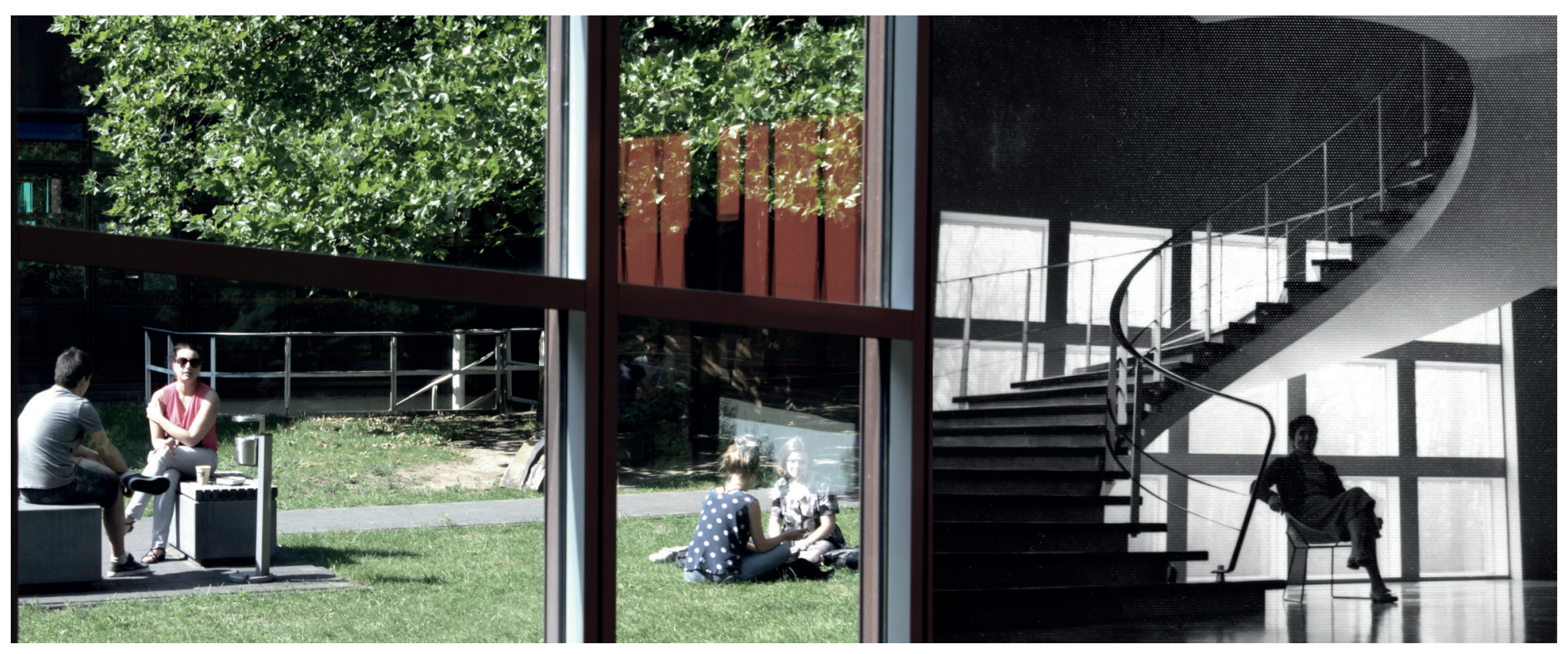




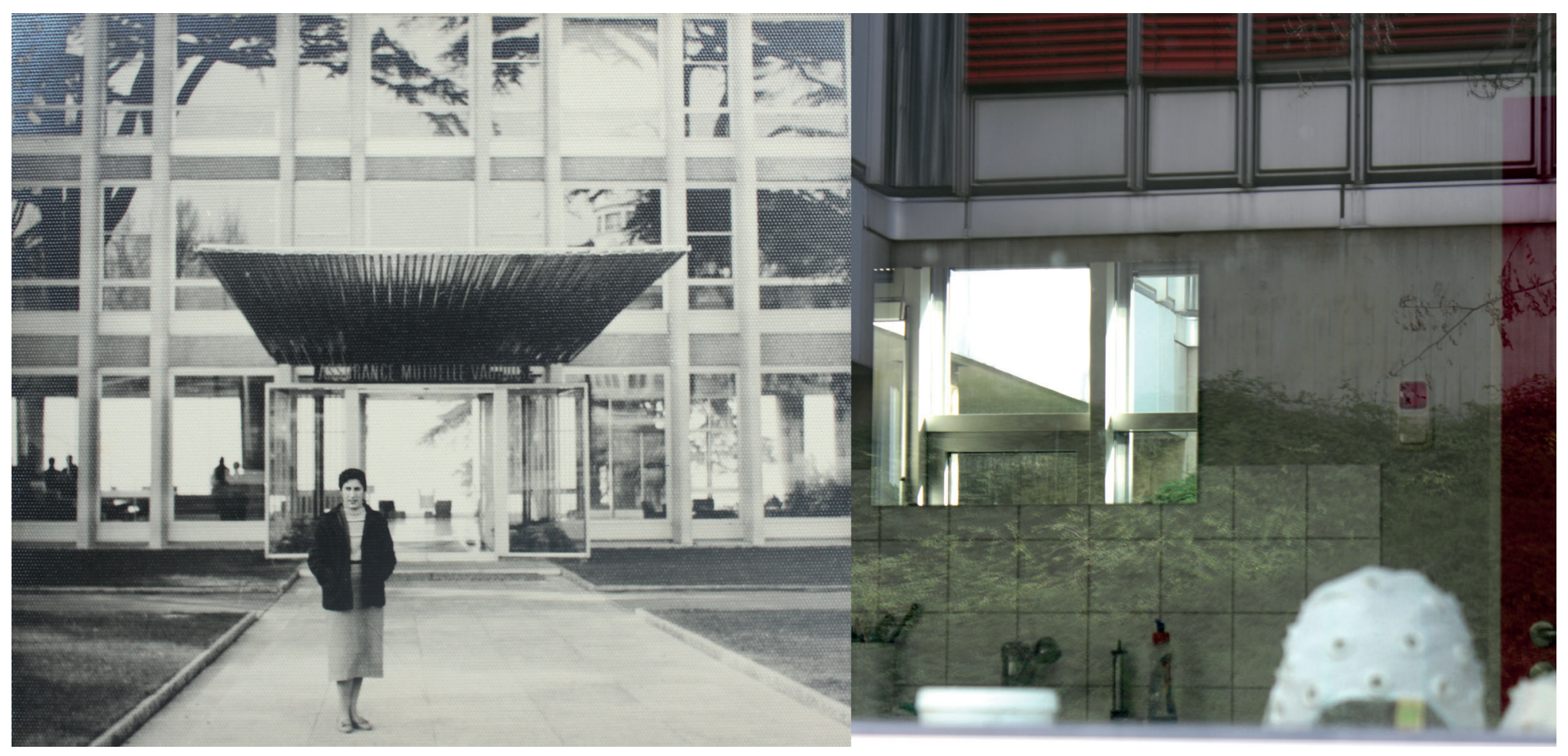




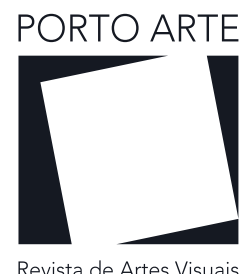

v. 24 n. 42

nov/dez 2019

e-ISSN:2179-8001

ENSAIO VISUAL

\section{Elaine Athayde Alves Tedesco}

Artista plástica com produção em fotografia, instalação e videoperformance. Doutora em Poéticas Visuais pela Universidade Federal do Rio Grande do Sul (UFRGS). É professora associada no Instituto de Artes da (UFRGS), atua junto ao Departamento de Artes Visuais e no Programa de Pós-Graduação em Artes Visuais. Desenvolve os projetos de pesquisa Videoarte: o audiovisual sem destino e Das ações com a câmera à instalação narrativa.

Visual artist with production in photography, installation and videoperformance. $P h D$ in Visual Poetics from the Federal University of Rio Grande do Sul (UFRGS). She is an associate professor at the UFRGS Institute of Arts, and works with the Department of Visual Arts and the Graduate Program in Visual Arts. Develops research projects Videoarte: the audiovisual without destination and From actions with the camera to the narrative installation.

Agradecimentos:

Jalba Athayde Alves Tedesco (mãe) e a Eleniz Bazacas, Dione Schneider, Lucia Maria Avancini e Diva Schneider que lhe deram o álbum de presente de aniversário no dia 10 de novembro de 1957 